\title{
The sense of the intact and the deconstruction of the self: Story as redemptive mediation
}

\author{
W.H. Willies \\ Department of English \\ Potchefstroom University for CHE \\ Vaal Triangle Campus \\ VANDERBIJLPARK
}

\begin{abstract}
The sense of the intact and the deconstruction of the self: Story as redemptive mediation

The notion of self is posed as a problematic which may fruitfully be approached by a close examination of the meaning of what story is. The problematic is resolved to some extent by the argument that story encompasses both the sense of the intact and the trace of deconstruction. Because the self indicates not only the empirical but also the numinous and ineffable, its relation to story is considered in terms of redemptive value. The mediative values of story are discussed by referring to the self as writer, reader and narrative. Because story offers an endless possibility of image and sequence, its co-dependence with self offers hope, possibility, and consequently, an imminent redemption.
\end{abstract}

\section{Introductory}

The trite but essential aphorism on which this article is based is that life is indivisible. The persuasion of vitalism is difficult to overcome even if it is granted that it is cerebral activity which has wrought the greatest changes in humanity. If this starting point is accepted, it becomes clear that language remains problematic, the discussion of which consequently proliferates in the spheres of both linguistic theory and literary theory. These spheres of theory are enabled and constructed further, as insights and comments continue with structural formation of these two established pillars of perspectives on language Thus they remain finm areas of abstruse scholarship and deliver few ideas powerful enough to make influential impact in any general way beyond academic discussion.

The purpose is to pose the question of what is left intact at this time in postmoden life. If academic discourse is permitted to become a mere fragment of life, obscured within specialisation, obfuscated by personal agenda and private 
purpose, it clearly loses the import of attempting to grapple with the inscrutable mysteries of life.

I am interested in the solid refusal - the noli me tangere - made by the irreducible phenomenon of the defiant self which baffles because of the limitations of intellectual questing. It is true that Christ offered this refusal in connection with his resurrected body before any assumption had been made. The question of whether the resurrected self has any relevance to the deconstructed self may not be impertinent. But if the self can be processed in both (and possibly more) of these amazing ways, the word loses integrity and becomes a psychic strategy instead of a spiritual unity. The incorruptible self then becomes something of a Holy Grail to which my being-in-itself is bound by quest rather than experience.

If I am a disciple of Gramsci, I admit that my sense of self is entirely contextual, that I can be distanced from the hegemonic, and simply play the institutional games from a lofty viewpoint of disengagement and consequent emancipation. For the professional teacher, loyalty to the intact is imperative. It is the definition of the intact which is problematic. Academic and scientific research, especially at the conceptual level, that refuses to be touched to the quick, misses its own intrinsic ethic. Yet, by definition, the intact remains intact either by deliberate or unconscious choice.

Nevertheless I wish to affirm that the irreducible aspect of the self is not entirely inscrutable. It seems to me that De Sausurre's time-honoured distinction between langue and parole has been appropriated without due concem for and recognition of the organic integrity which exists as intrinsic basis for this distinction. That organic unity may be explored by examining the self-consciousness and un-selfconsciousness of the self paradoxically within the impulses and cognition of the vital body, at once producing hegemonic and emancipatory awareness.

Academia does her students a disservice if she does not instill in them the paradoxical mixture of passion and precision in reading and interpreting the text of their individual experience. Reader-response theory impresses on us that such reading and interpreting are not passive but in fact, world-constructing, or, a term which is more modest, formative.

But how is the "irreducible self" to be approached? In the Zen tradition, Bankei's "Unborn" remains inscrutably clear. In humanistic psychology, Roger's "becoming" indicates the value of significant personal change. In the Christian perspective, the idea of incarnation brings home to this body, these hands, this skin, this alertness- and awareness-producing serotinin within, the organic unity of body, soul and spirit. 
I would like to suggest that the defiant self, subdued beneath obfuscation and deferment, finds a voice in the creativity which is the genesis of literature. Defiantly, creatively, the intangible announces its presence in the virgin paper of the unborn and the waverings of becoming. Resting in the velicle not of analytic discourse but of story it finds contact with the formative constraints of time and being. The current practice of using fiction as a model for philosophical process indicates that the story-tellers and writers may have at their disposal a natural means of going where philosophers, in all their history, desired to but could not go.

Thus what is at stake here is an understanding of what story means. Such an understanding will be approached from the perspective of bibliotherapy, the field in which meaningfulness and story seek not only contact but indeed fruition as a result of the effort of human integrity to express the inexpressible.

\section{Foundational concepts of story}

An important shift underlying the field is the move from the book, as such, to the story, the dynamic of engagement between mind and narrative. In the view of Stutterheim and Pretorius, bibliotherapy need not be strictly related to book form.

Bibliotherapy can be defined as the use of printed or non-printed material, fictitious or didactic. It is a process of interaction between reader and reading matter aiding the therapeutic process (Stutterheim \& Pretorius, 1993:9).

It is contended that this definition is an oversimplification: the process is not simply between "reader and reading-inaterial". The reading material, or more specifically, story, has therapeutic value rooted in the ontic structures of consciousness, incorporating affective as well as cognitive structures. The crucial issue is to ask what sort of a concept story is. Theories of narratology (e.g. Labov, Bremonde, Genette, Greimas) and theories of psychoanalysis (e.g. Freud, Jung) are too prolific to review succinctly for the purpose of offering analysis of theoretical compatibility of a multitude of points of departure. What is at stake is the uncovering of meta-theoretical constructs of story. It may be fruitful to regard the underpinnings of story as organic rather than structural. This means to say that the essential story, the mythos is a Gestalt and that to analyse, dissect or otherwise disturb its intrinsic cohesion is to arrive not at an understanding of story, but of a dismembered and dead body. Edwards (1984) defers fundamentally to subjectivity when he refers not outside of but within the mythos to carry out an understanding of story. His poetics of story is not an analysis, but a deepening of sensitivity to mythic origins. 
The sense of the imact and the deconstruction of the self: Story as redemptive mediation

Story, as the fiction of a fallen world remade, is in fact always in danger of losing the world by substituting itself, whatever its intention, of eventually dissatisfying its readers through its unreality (Edwards, 1984:90).

Josipovici (1973:48-49) falls with equal helplessness back to mythic rather than narrative values of story in discovering his meta-theory: "In order to help man see where his salvation lies God has written two books. The first of these is the Book of Scripture, which reveals to those who read it aright the working of God in man's history."

There is, however, a second book of which God is the author, as Josipovici suggests: "... the Book of Nature ... As God works through history, so he works through the world around us."

Marshack (1972:283) suggests that story is not merely a schema of narrative, but in fact a cognitive tool which finds a correlate in brain functionality. It is that natural path between experience and consciousness which has been (fortuitously) carved into stone and written on paper.

Far from finding its origin in a technology of mind, story is more like that which has resulted in an awareness which depends on a genesis which is both inter- and intra-personal. The poetics of story are not to be teased into a definition of advent: they are to find a way into the natural world, not the false world of striving mankind, but the created world of the Creator by a grace which fascinates and captures the alertness of the individual to himself. To put this in another way, the intellectual quest cannot be divorced from the whole of meaningfulness and isolated in an ambitious but necessarily fruitless way, but must find a harmony with a spiritual context which is to be perceived subjectively.

Egan (1989:2) states that "the story form is a cultural universal ... the story is not just some casual entertainment: it reflects a basic and powerful form in which we make sense of the world and experience".

The relation between story and salvation may not be entirely tenuous. Although it takes a considerable leap from the conceptual to the spiritual, this is the exact place where the individual finds the invitation to participate in the writing of his own fiction. Such an ultimately demanding but subtle task may be deferred only by an overwhelming historiography. This means to say that meaning is no abstraction but a fundamentally individual experience of ultimacy. Where such a sense of ultimacy capitulates to a self absorbed by the mass, or an institutionalised self, or a conceptualised self that does not know the freedom of the imagination, the story may be said to be incomplete. The sense of beginning and ending which are necessary elements of story are recognised to the extent that they are recognised by the artistry not of ponderous logic but the sharpness of intuition. A more direct way of putting this is to say that the enlightening story, 
the crux of realisation which is always just out of reach but which breaks into verbalised awareness from time to time needs an approach not of deliberate and clumsy demystification but of a more humble honouring.

The story is found when it is honoured by the imagination. The inagination relaxes into the story. No amount of scientific hammering will yield any story. This kind of aftirmation serves as challenge not to the validity but to the authority of scientific discourse. Put more bluntly, it may be stated thus: the ultimate paradigm of discovery and knowledge is not one of adherence to depersonalised analysis of structured and patterned concepts thus forming a theoretical view, but by active participation in the uncontrolled and gratuitous formation of the negotiable construct, the self. Essentially, story is the story of the self.

\section{Story and self}

Nell's comprehensive work, Lost in a Book (1988), sets out the various levels of neurological arousal and descriptions of mood which prevail when one engages with story (Nell, 1988:199-225). The point to be made here is that these levels and descriptions strongly suggest a relativisation of identity to mood and altered states of consciousness. The firm attachment between mood and language may be a suitable point at which to locate the rubric - the story - of individual meaning. The noli me tangere, no matter whether construed as the disappearing laughter of the trickster, the unapproachable virgin, or the secrets of the old fathers, is the secret which the self holds dear and will not surrender except in oblique ways. One cannot switch on the floodlight to exorcise the demon of distrust. Nor does one walk on water to disaffect the demon of unbelief. As in Yeats' Long-Legged Fly, the mind that moves upon silence is the mind that attempts to penetrate the intact, and finds that it is not action, but contemplation which discovers the inexpressible things of the self.

The self is the truest image of God in which mankind is made because of its intense privacy and yet its vivid generosity of possibility. Its proliferate capacity for relationship, imagination and creativity is matched by its stubbom refusal to yield up its hidden heart. All stories are stories of the self, reflecting the mundane and the magnificent, the intense and the diffident. No argument can suffice to establish the validity of such a claim, since faith, at this point, is persuaded not by logical conclusiveness, but by a creative act of imagination.

Does deconstructing the self penetrate the sanctity of the self? The discussion of the self finds interest largely within religious and phenomenal contexts; there have also been those like Hume who have denied the self a sensate location and have relegated it to the abstract and ineffable. In the Hindu tradition of "That art thou", the Brahman-Atman synthesis, the self and God are identified as one. In the Christian tradition, the self has been regarded as a nexus of evil which must 
The sense of the intact and the deconstruction of the self: Story as redemptive mediation

be surrendered to the Spirit of Christ for the work of redemption. St. Paul in his letter to the Romans attempts to deal categorically with the self and finds that the position is wretched because of the inability to choose conclusively either for good or for evil without the gracious intervention of Christ. Zen teaching has it that the illusory boundaries of the self are banished in the inarticulate experience of Satori, the enlightenment to the obvious.

So while philosophy must find the word abstruse, and religious viewpoints offer a variety of positions, literature signals the presence of the self in medias res, contemplating, reflecting and communicating. Noli me tangere is the hallmark not only of human presence but also of the questions put to the expression of human presence. The difference is one of style: while critical theory prowls and stalks, creativity dances, sings and plays. The sense of the intact self is currently challenged by the imperative not only to contextualise but also textualise the self. But if the self is to be textualised, the discourse, words and linguistic clues are bound by rhetoric, the coherent and cohesive sense of which is the irreducible mystique of the self. The argument here is that the self is revealed when its story is told. Psychotherapists will have no fight with the statement that the self is highly and often unconsciously selective about telling its story, even to itself. The key issue here is that of risk. Proven theory knows no risk: that is the precise point of its scientific status. But this is not the methodology of the forming self. The reified self is a mere caricature of the self: the saved self is not the living, struggling self poised on the edge between preverbalisation and the declared, done and dead, no-more-excited self. The discussed self is not worth discussing and the analysed self is truly in need of redemption. The story, the mythos of the self is not the self but the disappearance of the self into the (spiritual) world which is the context of the self. The mythos, the avenue of escape, is the text, the linguistic signals of the story which tells of the trace of the self. Thus the self is never the living, slipping and sliding self. The moment it is spoken of it becomes the crucified self, in danger of a bright-eyed and determined theory of self. Killed off by discourse, it is better left dead, to await the resurrection of a glimpsed recognition which honours the fact that the dead are beyond grasp.

The clear point to emerge from this attempt to allude to the unapproachable self is that the mysterium of the self and the mysterium of story are mutually implied. That human awareness cannot be reduced to theoretical constructs does not imply that the margin of experience between awareness and spirituality is undiscussable. For any amount of fruitful or fruitless purposes, self, story, experience and spirituality may be discussed. But that is not the point. The point is that story is praxis, an indicator of context and activation within context. To ask what the context of story is, is to head directly for the limits of language. On a theoretical basis, the more comprehensive approaches may well be found in the discourse of cognitive anthropology, beginning with Levi-Strauss (1973) and 
moving from there to contemporary writers such as Marshack (1972) or Bloch (1991). The purpose of story is not to abstract but to change, in fundamental ways, the typically human sense of self. Ascribing such change to artistry, Padavano (1979:6) puts the matter thus:

How do we change the vision of the people? It is love that art and religion have most in common. The artist convinces us of the truth by dealing with us holistically. Artists try to make us feel the truth. Good art gets the truth inside us on a level deeper than the surface of our minds. On this level, truth is most irresistible. The mind may not only resist the truth but may even accept it and keep it at a personal distance. Logical convictions are not necessarily existential imperatives. The artist makes us nostalgic for the beauty we have missed, the life we have forfeited, the meaning which somehow eluded our grasp. Art haunts us with the spectre of a lost humanity and bids us return to paradise.

Thus the hallmark of effective story is irrevocable change within the consciousness of the individual. The essence of story is the residue of irrevocable trace, an amalgam of thought, belief, mood and attitude. Although story may lead to intellectual and emotional conviction, it is not to be equated with conviction, since it is a praxis of the imagination, which is independent of logic. The question of whether conviction is to be regarded as rational or irrational is pertinent at this point. The question may be answered in this way: since information is always incomplete, axionatically, conviction must always involve premature closure. Closure, however, is a function of rationality. Imagination knows nothing of closure. Story does not convert, it merely changes. Story, as focus and vehicle of change, eclipses the self at the intense risk of the anomie of impersonality. Thus the enigma of the unconscious marriage between story and self defies definition and can only be expressed in the surprising movement of the present. The philosophical issue is not the question of priority of existence or essence but the issue of experience needing a mediating rubric. According to Marshack (1972:133) Stone Age man knew no discontinuity between explanation and story. The essential rubric of explanation which story serves has not changed, although human mentality certainly has. The problem of discussing contemporary story, within the fashionability of post-Inodernism, is the problem of change itself being so elusive that intellectual activity becomes a logjam, not because of a lack of impulse or movement, but because of a proliferation of subtle data. Story, however, does not take cerebral activity as a sole starting point Organically constituted, story follows the geography of the body, moving between awareness and image, accountable to the intellect only on the basis of accuracy of sensate description. All else is mere intellectualism, which, as a science, is defiant of the sense of the intact, and can have no truck with what is essentially mystical. The sense of self which is at stake here is not the consciously intact self, which is always false because of necessarily premature 
closure, but the unconsciously intact self, recognised as such by the conscious self, and respected as such, because the story of the apprehension by the conscious self of the unconscious self is the story of irrevocable change. How such change may be the meaning of the redemption of the self will be discussed in the next and final section.

\section{Story as redemptive mediation}

Put bluntly, story is an account of the self by the self to the self. It is crucial to realise that the self is an artificial concept, referring to ontic relativity where boundaries between individual, other and community are blurred since reference to self is always creative as well as quasi-definitive. It is assumed that such an account is not done in a private language and is not to be reduced to a psychologism. Story and utterance are not to be divorced. The theory of condensed sub-vocalisation is relevant to the organic nature of story, if story is to be rooted to the body, and not merely conceptualised as an abstracted series of mental acts.

Narrating is never innocent and the narrative that frames another allows the writer to dramatize the results of the telling. And this no doubt signals to the reader that the tale told can and should react on his own life: that literature is not inconsequential (Brooks, 1994:77-78).

If the dynamics of the self adopt the roles of writer, reader and narrative, but escape the confines of privacy by being subject to utterance, self-change becomes open to scrutiny and discussion. The point of this section is to offer a point of contact between such articulated change and spirituality. The reason for this is to test the sense of privacy against the imperative of ultimacy. If story is a product of both the intact and the generous soul, it is the path towards the boundaries of interpretation which are the basis of value. Here language loses everything except aesthetic value.

... is there possible experience pre- or non-linguistic? If I were put to it I should argue that although most of what enters experience is not merely linguistic, whatever enters experience does so in and with language, that in this sense we inhabit the world linguistically. But even if we grant that we may experience something in the utter absence of language: still, if an experienced present is not simply a disassociated 'now' but contains a vestige of memory and a leaning into anticipation, then an incipient narrative form will be implicit in it, of which narrative language is the irreducible linguistic expression. However we settle the question about non-linguistic experience, there is still an intimate relation between storytelling and the aesthetic form of experience itself (Crites in Wiggins, 1985:32). 
The link between story and spirituality contains elements both of poetics and aesthetics in the foundational quest for redemption of awareness. Such redemption is not seen here as some kind of quasi-theological abstraction, but as a coherent but rare intuition of the dynamics of vitalist depth. The vehicle of language in this regard is not fruitful if used in a purely intellectualist way: the details of spiritual awareness, teased out into story, offer not dogma but recognition of individuality and singularity against the backdrop of communality. The argument here is that it is precisely such recognition that is the closest understanding of what story is. When one experiences the sense that one is known, to another, to oneself, even to the Divine, one is changed. When the therapeutic values of story are served, not only individual awareness but also communal awareness is offered a moment of irrevocable change, the essence of which is potent generosity, the highway of hope. It may not be denied that the zone between the writer and the reader is hazardous, and that misinterpretation is unavoidable. But this may be put down to imınaturity of spiritual formation rather than paucity of meaningfulness. In any case, meaningfulness is no abstraction of experience, but indeed, too detailed to be apprehended - let alone comprehended in a purely intellectualist way. The affirmation which is made here is that story and spiritual fornation are co-dependent. Spiritual formation in this sense refers to that change which happens conjointly with utterance of that which is unconscious or secret to the individual. In other words, that which is intact, that which may be deconstructed and that which is narrated have in common an unknown area of potential revelation. This area is not only unknown but also unknowable since revelation is not epistemic but prophetic. Here at last is the clear link between prophetic language and redemption. Again, the basic argument is that story is concerned with change, and cliange in turn with individual awareness. The crucial issue is the narrative that expresses the change, in ways which are both oblique and clear. Whereas the latter is accessible to the intellect, the former is organically shrouded in visceral experience. Story, the Gestalt which encompasses the entire organic experience, portrays and hides the mysterium but allows, within this paradox, endless possibility of sequence and image. It is this possibility to which awareness is called, and to declare in acts and utterances of courage the realisation of life in the created order.

It may be said, then, that story is that which mediates between the self and the world. In itself, story holds promise of creation, but not without the risk that attends the creative act. Its redemptive action is implied in its metaphoric play and especially in its fluency of value impact. The parables of the New Testament are a case in point. It is instructive to note that the very incarnation of the Divine life taught by means of story. To hammer home the point, the story of the crucifiction and resurrection is best approached not by resorting to classifications either of fact or fiction, but by participation in the passion and promise of the Divine love which is both revealed and hidden within a fathomless grace 
The sense of the intact and the deconstruction of the self: Story as redemptive mediation

\section{Bibliography}

BLOCH, M. 1991. Language, Anthropology and Cognitive Science Man, 26(2):183-198, Jun.

BROOKS, P. 1994. Psychoanalysis and Storytelling Great Britain : Blackwell

EDWARDS, M. 1984. Towards a Christian Poetics. London : MacMillan.

EGAN, K. 1989. Teaching as Story-Telling Chicago : University of Chicago Press.

JOSIPOVICI, G. 1973. The World and the Book. United Kingdom : Paladin

LEVI-STRAUSS, C. 1973. Structural Anthropology. London : Lane.

MARSHACK, A. 1972 The Roots of Civilisation. New York : McGraw-Hill

PADAVANO, A 1979. Aesthetic Experience and Redemptive Grace (In Aesthetic Dimensions of Religious Education Durka, G \& Smith, J. eds. Ramsey, N.J. : Paulist Press )

NELL, V. 1988. Lost in a Book. New Haven : Yale University Press

STUTTERHEIM, H. \& PRETORIUS, C. 1993. The Use of Bibliotherapy in the Treatment of Abused Children. Social Work Practice, 1:7-12.

WIGGINS, J.B ed. 1985. Religion as Story New York: Harper and Row. 